\title{
The Association between Related Party Transactions and Real Earnings Management: Internal Governance Mechanism as Moderating Variables
}

\author{
Genius Khober Limanto ${ }^{1}$, and Antonius Herusetya ${ }^{1, *}$ \\ ${ }^{1}$ Accounting Department, Business School, Universitas Pelita Harapan, Tangerang, Indonesia
}

\begin{abstract}
We investigate the association between related party transactions (RPT) and real earnings management (REM). We also investigate the role of internal governance mechanism through the effectiveness of board of commissioner and audit committee in mitigating the association between RPT and REM. Our research sample consists of 386 firm-years of manufacturing firms listed in Indonesian Stock Exchange (IDX) from year 2010 - 2014. Using linear regression, we find evidence that RPT has positive association with REM, only when the firm has higher RPT but not in the lower RPT. We find a contradictory result that board of commissioners strengthen the positive association between RPT and REM. Finally, we find evidence that the effectiveness of audit committees weaken the positive association between RPT and REM, both in full sample and in high RPT sample.

Keywords: related party transactions, real earnings management, board of commissioner, audit committee, corporate governance
\end{abstract}

\section{Introduction}

One of the consequences of agency problem between controlling and minority shareholders is the practice of earnings management (EM) by controlling shareholders. And related party transactions (RPT) have been used as means of earnings management. Sales to related parties could be used opportunistically to manage earnings upwards and to present more positive operating performance [1]. In addition, certain types of RPT, such as lending to other firms controlled by the same controlling shareholders, have been used by companies to divert earnings from operations to their controlling shareholders and to expropriate their minority shareholders' wealth to maximize the wealth of the controlling shareholders [2]. Firms that engage in RPT which expropriate the minority shareholders are more likely to engage in earnings management than firms without such transactions [3].

\footnotetext{
${ }^{*}$ Corresponding author: antonius.herusetya@uph.edu
} 
Weak corporate governance mechanism has a role in allowing the practice of earnings management, while an effective corporate governance functions were found to have significant negative influence on earnings management practice because they play an important role in overseeing the quality of reported earnings [4, 5]. A study also found that companies with weaker corporate governance mechanism have more and higher RPT which imply agency problem between managers and shareholders [6]. Those with better mechanism have less and lower RPT which imply that corporate governance is important in deterring manipulation through RPT.

There are some research gaps in the previous studies. First, only few researches about RPT and EM have been conducted in Indonesia. Second, previous studies had shown mixed results on the association between RPT and EM. Kuan [2] did not found any evidence of the association between aggregated RPT and absolute discretionary accruals. Others found only positive association between purchases and expenses from related party, and abnormal accruals [7]. Third, previous researches applied different methods of measuring RPT and EM, and recognized that those were not good enough to capture the phenomena of RPT [2,7]. Fourth, Kuan [2] recognized that using only RPT was not enough to explain EM behavior and suggested to include more characteristics, such as Indonesian ownership structure and corporate governance mechanism. Our study contribute to the other measurement of EM i.e., real earnings management (REM), since it is believed that REM is the preferred method to manage earnings $[8,9] \mathrm{We}$ also investigate whether board of commissioners (BCE) and audit committee (ACE) have moderating effect in the association between RPT and REM.

\section{Hypothesis development}

Prior studies indicates mixed results in the association of RPT and earnings management (EM). Sumiyana and Febrianto [7] for example, discovered that purchase and expenses from transaction with related party had positive influence towards EM. Kuan [2] did not find significant relationship between related party transactions (RPT) and EM. Munir [3] found that RPT that resulted in expropriation activities negatively affect earnings quality of firms with significant family ownership. This low earnings quality was likely resulted from earnings management to mask the firm's poor performance resulted from expropriation. Those prior researches focus only in the accrual earnings management (AEM) while companies prefer using REM because it is more difficult to be detected by auditors $[8,9]$. We proposed our hypothesis as follows:

$\mathrm{H}_{1}$ : There is positive association between related party transactions and real earnings management.

Hermawan [5] found that the effectiveness of board of commissioners had positive association with earnings quality. She also found that the effectiveness of audit committee had positive association with earnings quality in a company if board of commissioners were not function effectively. Audit committee characteristic has negative association with earnings management [4]. These studies suggest that if corporate governance functions effectively then the earnings management can be minimize. And because of the corporate strategies in RPT and REM is under the control of internal governance mechanism [5], we expect that the effectiveness of board of commissioners and audit committee could weaken (strengthen) the positive (negative) association between RPTs and REM. So our proposed hypothesis is as follows:

$\mathrm{H}_{2}$ : The effectiveness of board of commissioners weakens (strengthens) the positive 
(negative) association between related party transactions and real earnings management.

$\mathrm{H}_{3}$ : The effectiveness of audit committee weakens (strengthens) the positive (negative)

association between related party transactions and real earnings management.

\section{Research design}

\subsection{Data and sample selection}

We use purposive sampling method in our sample selection from manufacturing industries listed in Indonesian Stock Exchange (IDX) from the year 2010 - 2014 with the criteria i.e., the firms have complete disclosure about the nature and extent of their related party transactions (RPT), their boards of commissioners, their audit committee, and their financial performance in their annual reports; and firms used Rupiah as their currency in the financial reports.

\subsection{Empirical model}

Following Munir [6], we use empirical models to test the first hypothesis $\left(\mathrm{H}_{1}\right)$ as follows:

$$
\begin{aligned}
& R E M I D X_{\mathrm{i}, \mathrm{t}}=\beta_{0}+\beta_{1} R P T_{\mathrm{i}, \mathrm{t}}+\beta_{2} A B S D N I_{\mathrm{i}, \mathrm{t}}+\beta_{3} L O S S_{\mathrm{i}, \mathrm{t}-1}+\beta_{4} M T B_{\mathrm{i}, \mathrm{t}-1}+\beta_{5} L E V_{\mathrm{i}, \mathrm{t}} \\
& +\beta_{6} \operatorname{LogASSETS~}_{\mathrm{i}, \mathrm{t}}+\beta_{7} \text { BIG }_{\mathrm{i}, \mathrm{t}}+\mathrm{e}_{\mathrm{i}, \mathrm{t}}
\end{aligned}
$$

And using following regression model to test $\mathrm{H}_{2}$ and $\mathrm{H}_{3}$ :

$$
\begin{gathered}
R E M I D X_{\mathrm{i}, \mathrm{t}}=\beta_{0}+\beta_{1} R P T_{\mathrm{i}, \mathrm{t}}+\beta_{2} R P T_{\mathrm{i}, \mathrm{t}} * B C E_{\mathrm{i}, \mathrm{t}}+\beta_{3} R P T_{\mathrm{i}, \mathrm{t}} * A C E_{\mathrm{i}, \mathrm{t}}+\beta_{4} A B S D N \mathrm{I}_{\mathrm{i}, \mathrm{t}} \\
+\beta_{5} \operatorname{LOSS}_{\mathrm{i}, \mathrm{t}-1}+\beta_{6} M T B_{\mathrm{i}, \mathrm{t}-1}+\beta_{7} L E V_{\mathrm{i}, \mathrm{t}}+\beta_{8} \log A S S E T S_{\mathrm{i}, \mathrm{t}}+\beta_{9} B I G 4_{\mathrm{i}, \mathrm{t}}+\mathrm{e}_{\mathrm{i}, \mathrm{t}}
\end{gathered}
$$

Based on prior studies, we predict that related party transactions (RPT) have positive association with real earnings management (REMIDX) [3, 7]. The moderating role of board of commissioners and audit committee are represented by RPT*BCE and RPT*ACE, and we predict that these variables have negative associations with REMIDX [4, 5].

\subsection{Operational variable}

The dependent variable of this research is real earnings management (REMIDX). We use REM in aggregate level (REMIDX) instead of individual level, i.e., the sum of abnormal cash flow from operations (CFO), abnormal production cost (PROD), and abnormal discretionary expense (DISC), because management can engages real transactions by using combination of it [8]. The following is the equation for normal CFO.

$$
\frac{\text { CFO }_{\mathrm{i}, \mathrm{t}}}{\text { Assets }_{\mathrm{i}, \mathrm{t}-1}}=\mathrm{k}_{1} \frac{1}{\text { Assets }_{\mathrm{i}, \mathrm{t}-1}}+\mathrm{k}_{2} \frac{\text { Sales }_{\mathrm{i}, \mathrm{t}}}{\text { Asset }_{\mathrm{i}, \mathrm{t}-1}}+\mathrm{k}_{3} \frac{\Delta \text { Sales }_{\mathrm{i}, \mathrm{t}}}{\text { Asets }_{\mathrm{i}, \mathrm{t}-1}}+\mathrm{e}_{\mathrm{i}, \mathrm{t}}
$$

Production cost (PROD) consists of cost of goods sold and changes in inventory. The following is the equation for normal PROD.

$$
\begin{aligned}
\frac{\operatorname{COGS}_{\mathrm{i}, \mathrm{t}}+\Delta I N V_{\mathrm{i}, \mathrm{t}}}{\text { Assets }_{\mathrm{i}, \mathrm{t}-1}} & =\mathrm{k}_{1} \frac{1}{\text { Assets }_{\mathrm{i}, \mathrm{t}-1}}+\mathrm{k}_{2} \frac{\text { Sales }_{\mathrm{i}, \mathrm{t}}}{\operatorname{Assets}_{\mathrm{i}, \mathrm{t}-1}}+\mathrm{k}_{3} \frac{\Delta \text { Sales }_{\mathrm{i}, \mathrm{t}}}{\text { Assets }_{\mathrm{i}, \mathrm{t}-1}} \\
& +\mathrm{k}_{4} \frac{\Delta \operatorname{Sales}_{\mathrm{i}, \mathrm{t}-1}}{\text { Asset }_{\mathrm{i}, \mathrm{t}-1}}+\mathrm{e}_{\mathrm{i}, \mathrm{t}}
\end{aligned}
$$

Discretionary expenses (DISEXP) consist of selling expenses, general and administrative expenses, and research and development expenses. The following is the equation for normal DISCEXP. 


$$
\begin{array}{r}
\frac{\operatorname{DISC}_{\mathrm{i}, \mathrm{t}}}{\operatorname{Assets}_{\mathrm{i}, \mathrm{t}-1}}= \\
\mathrm{k}_{1} \frac{1}{\operatorname{Asset}_{\mathrm{i}, \mathrm{t}-1}}+\mathrm{k}_{2} \frac{\text { Sales }_{\mathrm{i}, \mathrm{t}-1}}{\text { Assets }_{\mathrm{i}, \mathrm{t}-1}}+\mathrm{e}_{\mathrm{i}, \mathrm{t}}
\end{array}
$$

We run the data through these three equations (3-5) so that we get the residual errors $\left(\mathrm{e}_{\mathrm{i}, \mathrm{t}}\right)$ of each equation, and the sum of standardized value of each abnormal CFO, PROD, and DISEXP are REMIDX. We follow Chi [10] to determine the aggregated value of REM (REMIDX) that is, - Standardized Abnormal CFO + Standardized Abnormal PROD - Standardized Abnormal DISC. Data for RPT are collected from transactions disclosed in the Related Party Transactions section in Notes to the Financial Statements (i.e., acquisition of assets from related party, assets sales to related party, equity sales to related party, trading relationship with related party, and cash payment or loan to related party). RPT variable is the total RPT that could result in expropriation of minority shareholders divided by total sales in year t. Our sample are grouped into two sub-sample (i) firms with high RPTs (i.e., equal to or more than 1 percent of firm's total sales), and (ii) low RPT (i.e., less than $1 \%$ of firm's total sales) [3].

Board of commissioners' effectiveness (BCE) and audit committees' effectiveness (ACE) are moderating variables. The values of these variables are determined by checklists

Table 1. Selected descriptive statistics of key variables

\begin{tabular}{lccccc}
\hline \multicolumn{1}{c}{ Variables } & n & Mean & Min & Max & Std. Dev \\
\hline REMIDX & 386 & -0.00 & -8.331 & 11.804 & 2.231 \\
ABCFO & 386 & 0.005 & -1.158 & 0.960 & 0.184 \\
ABPROD & 386 & 0.223 & -0.653 & 5.591 & 0.486 \\
ABDISEXP & 386 & -0.126 & -0.466 & 1.086 & 0.164 \\
RPT & 386 & 0.213 & 0.00 & 1.488 & 0.318 \\
BCE & 386 & 0.614 & 0.00 & 1.00 & 0.487 \\
ACE & 386 & 0.850 & 0.00 & 1.00 & 0.358 \\
\hline
\end{tabular}

based on Hermawan [5]. BCE is a dummy variable with the value of 1 if the score of $\mathrm{BCE}$ of a company is equal and above 34 and 0 otherwise. ACE is a dummy variable with the value of 1 if the score of ACE of a company equal and above 22 and 0 otherwise. To determine the moderating effect of $\mathrm{BCE}$ and $\mathrm{ACE}$, each of $\mathrm{BCE}$ and $\mathrm{ACE}$ is multiplied by RPT.

\section{Results and discussion}

\subsection{Descriptive statistics}

Table 1 presents the mean, minimum, and maximum value of key variables used in the empirical model. The mean of real earnings management in aggregate level (REMIDX) is almost zero, while in individual measures is $0.005,0.223$ and -0.126 each for abnormal operating cash flows (ABCFO), abnormal production (ABPROD), and abnormal discretionary expense (ABDISEXP). The mean of related party transactions (RPT) is 0.213 or $21.33 \%$ of firm's total sales. 


\subsection{Test of association between RPT and REM (H1)}

The regression results of hypothesis 1 (H1) are presented in Table 2. Our main variable RPT with all sample $(n=386)$ has a coefficient of $0.236(t-s t a t=0.78)$, not significant at 0.10 . We perform additional test with our sub-sample of high RPT and low RPT. We find evidence that the coefficient of RPT in sub-sample with high RPT is positive $\left(\beta_{1}=0.922\right.$, t$s t a t=2.87$ ) and significant at 0.01 , but not significant in sample with low RPT (i.e., the coefficient has t-stat of -1.16). Our findings are consistent with our early prediction (H1) that related party transaction has a positive association with earnings management only if in the condition of sub-sample with high RPT, but not with low RPT. This findings indicate that high related party transactions in a firm can be used as earnings management tools, specifically in the aggregate level of real transactions to expropriate minority shareholders.

Table 2. Test of hypothesis 1 (H1)

\begin{tabular}{|c|c|c|c|c|c|c|c|}
\hline \multicolumn{8}{|c|}{ Dependent variable: REMIDX } \\
\hline \multirow{3}{*}{$\begin{array}{l}\text { Main } \\
\text { variables }\end{array}$} & \multirow{3}{*}{$\begin{array}{l}\text { Predicted } \\
\text { sign }\end{array}$} & \multirow{2}{*}{\multicolumn{2}{|c|}{ All sample }} & \multicolumn{4}{|c|}{ Sub-sample } \\
\hline & & & & \multicolumn{2}{|c|}{ High RPT } & \multicolumn{2}{|c|}{ Low RPT } \\
\hline & & Coefficient & t-stat & Coefficient & t-stat & Coefficient & t-stat \\
\hline RPT & + & 0.236 & 0.78 & 0.922 & $2.87 * * *$ & -7.710 & -1.16 \\
\hline Adj. $\mathrm{R}^{2}$ & & 0.112 & & 0.147 & & 0.014 & \\
\hline Prob (F) & & 0.000 & & 0.000 & & 0.008 & \\
\hline No. of Obs. & & 386 & & 256 & & 130 & \\
\hline
\end{tabular}

\subsection{Test of moderating role of internal governance mechanism ( $\mathrm{H} 2$ and $\mathrm{H} 3$ )}

First, we investigate with all sample on how board of commissioners and audit committees have role in the association between RPT and real activities. Table 3 presents the result of robust regressions of the second and third hypotheses $\left(\mathrm{H}_{2} \& \mathrm{H}_{3}\right)$. We found that the moderating variables RPT*BCE has positive coefficient of $1.678(\mathrm{t}$-test $=3.08)$ significant at 0.01 , contrary to our hypothesis. On the other hand, the coefficient of RPT*ACE is 1.503 ( $\mathrm{t}$-stat $=-2.37$ ) significant at 0.05 , consistent with our hypothesis. We also perform further tests with sub-sample of high RPT $(n=256)$ and low RPT $(n=130)$ to get robust results. With high RPT sample, variable RPT*BCE has positive coefficient of 1.478 (tstat $=2.42$ ), significant at 0.05 , while in the low RPT sample the coefficient is not significant $(\mathrm{t}$-stat $=-0.06)$. Also in Table 3 , with high RPT sample variable RPT*ACE has coefficient of -1.400 ( $\mathrm{t}$-stat $=-2.13$ ), significant at 0.05 , while in low RPT sample, RPT*ACE has coefficient of $0.685(\mathrm{t}-\mathrm{stat}=0.28)$, not significant.

With our full sample and sub-sample tests, we conclude that the board of commissioners (BCE) do not function effectively as we predict to minimize (weaken) the association between RPT and real earnings management, especially with high RPT sample. This result implies that when firm's RPTs are equal to or higher than 1 percent of total sales, board of commissioners strengthens the positive association between RPT and REM. Our results give interpretation that the board of commissioners might get involve with the RPT in the strategic level to increase the performance of the firms by engaging real activities. On the other hand, in general and with high RPT sample, we found consistent results that the effectiveness of audit committees (ACE) weaken the association between RPT and REM, consistent with previous study [5]. 


\section{Conclusion}

We investigate the association between related party transactions (RPT) and real earnings management (REM). Using linear regressions, we find evidence that there is a positive association between RPT and REM, only when the firm has higher RPT but not in the lower RPT $[3,7]$. We also investigate the role of internal governance mechanism through the

Table 3. Test of hypothesis $2(\mathrm{H} 2)$ and hypothesis $3(\mathrm{H} 3)$

\begin{tabular}{|c|c|c|c|c|c|c|c|}
\hline \multicolumn{8}{|c|}{ Dependent variable: REMIDX } \\
\hline \multirow{3}{*}{$\begin{array}{l}\text { Main } \\
\text { variables }\end{array}$} & \multirow{3}{*}{$\begin{array}{l}\text { Predicted } \\
\text { sign }\end{array}$} & \multirow{2}{*}{\multicolumn{2}{|c|}{ All sample }} & \multicolumn{4}{|c|}{ Sub-sample } \\
\hline & & & & \multicolumn{2}{|c|}{ High RPT } & \multicolumn{2}{|c|}{ Low RPT } \\
\hline & & Coefficient & t-stat & Coefficient & t-stat & Coefficient & t-stat \\
\hline RPT & $+/-$ & 0.190 & 0.30 & 0.906 & $1.49^{\wedge}$ & -1.758 & -0.70 \\
\hline $\mathrm{RPT} * \mathrm{BCE}$ & - & 1.678 & $3.08^{* * *}$ & 1.478 & $2.42 * *$ & -0.817 & -0.06 \\
\hline RPT*ACE & - & -1.503 & $-2.37 * *$ & -1.400 & $-2.13 * *$ & 0.685 & 0.28 \\
\hline Adj. $R^{2}$ & & 0.109 & & 0.166 & & 0.129 & \\
\hline Prob (F) & & 0.000 & & 0.000 & & 0.000 & \\
\hline No. of & & 386 & & 256 & & 130 & \\
\hline $\begin{array}{l}\text { Obs. } \\
* * * * * \text { rer }\end{array}$ & 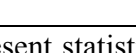 & .8 & 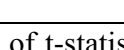 & set 1 nerce & and 5n & ont levels re & \\
\hline
\end{tabular}

board of commissioners and audit committee in mitigating the association between RPT and REM. We find a contradictory result with our hypothesis i.e., the board of commissioners strengthen the positive association between RPT and REM especially in our high RPT sub-sample. Our alternative explanation to this is that the board of commissioners might involve themselves in the expropriation of minority shareholders' wealth by engaging real activities. Finally we find consistent results with our hypothesis that the effectiveness of audit committees weaken the positive association between RPT and REM [5]. We propose accruals and real transaction to be examined together for further study instead of REM only [9].

\section{References}

1. J. J. Chen, P. Cheng, X. Xiao. Related party transactions as a source of earnings management. AFE, 21 (3), 165-181 (2011).

2. L. Kuan, G. Tower, R. Rusmin, J. W. M. Van der Zahn. Related party transactions and earnings management. JAAI, 14 (2), 115-137 (2010).

3. S. Munir, N. M. Saleh, R. Jaffar, P. Yatim. Family ownership, related-party transactions and earnings quality. Asian Academy of Management Journal of Accounting and Finance, 9 (1), 129-153 (2013).

4. A. Klein. Audit committee, board of director characteristics, and earnings management. JAE, 33, 375-400 (2002).

5. A. A. Hermawan. The influence of effective board of commissioners and audit committee on the informativeness of earnings: evidence from Indonesian listed firms. APJAF, 2 (1), 1-38 (2011).

6. E. A. Gordon, E. Henry, D. Palia. Related party transactions: associations with corporate governance and firm value in EFA 2004 Maastricht Meeting Paper \& AFA (2004). 
7. Sumiyana, R. Febrianto. Related parties' transaction and earnings management: a case in Indonesia. Jurnal Ekonomi dan Bisnis Indonesia, 27, 192-209 (2012).

8. D. A. Cohen, A. Dey, T. Z. Lys. Real and accrual-based earnings management in the pre-and post-Sarbanes-Oxley periods. TAR, 83 (3), 757-787 (2008).

9. S. P. Kothari, N. Mizik, S. Roychowdhury. Managing for the moment: The role of earnings management via real activities versus accruals in SEO valuation. TAR, 91 (2), 559-586 (2016).

10. W. Chi, L. L. Lisic, M. Pevzner. Is enhanced audit quality associated with greater real earnings management? AH, 25 (2), 315-335 (2011). 